Man and Nature

L'homme et la nature

\title{
Women Artists in Eighteenth-Century France
}

\section{Howard V. Evans et Charlotte B. Evans}

Volume 1, 1982

URI : https://id.erudit.org/iderudit/1011803ar

DOI : https://doi.org/10.7202/1011803ar

Aller au sommaire du numéro

Éditeur(s)

Canadian Society for Eighteenth-Century Studies / Société canadienne d'étude du dix-huitième siècle

ISSN

0824-3298 (imprimé)

1927-8810 (numérique)

Découvrir la revue

Citer cet article

Evans, H. V. \& Evans, C. B. (1982). Women Artists in Eighteenth-Century France. Man and Nature / L'homme et la nature, 1, 199-207.

https://doi.org/10.7202/1011803ar

Copyright (C Canadian Society for Eighteenth-Century Studies / Sociéte canadienne d'étude du dix-huitième siècle, 1982
Ce document est protégé par la loi sur le droit d'auteur. L'utilisation des services d'Érudit (y compris la reproduction) est assujettie à sa politique d'utilisation que vous pouvez consulter en ligne.

https://apropos.erudit.org/fr/usagers/politique-dutilisation/ 


\section{Women Artists in Eighteenth- Century France}

\section{The Eighteenth Century in Perspective}

The decade of the 1970s will undoubtedly go down in history as a period that witnessed a dramatic renaissance (some might say revolution) in the history of women artists. The birth of the Women's Caucus for Art, the Feminist Art Journal, and the Center for Feminist Art Historical Studies, all established in the early seventies, are but a few milestones in the movement. ${ }^{1}$ The celebration of International Women's Year in 1975 stimulated the publication of bibliographical sources, notably Vicki Lynn Hill's Female Artists, Past and Present. Capping the decade, Germaine Greer published her comprehensive but controversial Obstacle Race which will undoubtedly spark a new wave of reactions in the $1980 \mathrm{s.}^{2}$

In spite of the dramatic increase in interest in women's art, no one has made a quantitative analysis of women artists of a particular period. No one, for example, has attempted to analyze and evaluate the phenomenal increase in the number of French women artists during the Enlightenment. It was for this reason that the present investigation of women artists was initiated several years ago. The study is more concerned with women artists as a professional group than as individuals. The approach is both analytical and biographical, examining such questions as why escalating numbers of French women turned to art as a vocation in the eighteenth century; from what economic classes they emerged; from whom they learned their crafts; the nature of their marital relationships; and the extent of their success, financially and professionally, in competing with male artists.

Within Europe, France clearly excelled in the number and quality of active women artists during the Enlightenment. This is not surprising because France contained the three essential ingredients necessary for the emergence of women as professionals: an abundant supply of male artists, a society sufficiently mobile to encourage women to enter the professions, and a substantial middle class. The first ingredient was necessary because almost all of the women learned their crafts in the workshops of male artists. Only toward the end of the century did an increasing number of women learn to paint in the studios of other women, but this practice was the exception rather than the rule. Consequently, the number of female artists in a particular locality or country tended to be proportional to the number of male artists, provided that the other prerequisites existed. ${ }^{3}$ In a century which produced 
Watteau, Boucher, Greuze, Chardin, Fragonard, and David, France could be expected to give birth to a proportionally large number of female painters as well. And this was true; indeed, as France displaced Italy as the cultural center of Europe in the eighteenth century, Paris and its environs also became the artistic showcase for women artists. ${ }^{4}$

The second ingredient, social mobility, was equally important in motivating women to turn to the brush and palette for a livelihood. In such socially rigid countries as Russia and Spain the number of women who became professionals was small even though there was an adequate supply of male artists. ${ }^{5}$ In France the social conditions were favorable in the eighteenth century because French society gave women increasing independence. The literary salons in the seventeenth and eighteenth centuries had already given a small but influential number of women unprecedented opportunities to exhibit their wit and literary talents. Through the salons French women had gained higher stature and influence in society. It is not surprising, therefore, that women artists were welcomed into the art salons of the Enlightenment. Women artists with great talent, e.g., Rosalba Carriera, Vigée-Lebrun and Angelica Kauffmann, were universally respected and celebrated. It is in this sense that Vigée-Lebrun's comment that women "reigned" in French society before the revolution "dethroned" them must be understood. ${ }^{6}$

Without the third ingredient - a sizeable middle class to buy art and artifacts - few women artists could have survived in the competitive marketplace. It was largely the mercantile, financial, and professional bourgeoisie that bought their works. Without this increasingly significant group of art patrons, the number of women who could have supported themselves solely through the sale of their works would have been appreciably smaller. A few women, notably Vigée-Lebrun, Labille-Guiard, and Marie Benoist, who found royal and noble patrons to buy their large canvasses, were not as dependent upon the middle classes, but even they found a ready market in the affluent bourgeoisie. Most of the other women artists in France (and elsewhere in Europe) found buyers almost solely in the upper bourgeoisie and country gentry.

This correlation of economic activity and cultural creativity was clearly manifested throughout Europe in the Enlightenment, and it explains the meteoric increase in women professionals in what might be called the Golden Age of women's artistry. In such countries as the Netherlands and in the city states of Renaissance Italy, this new class of bourgeois patrons had emerged earlier, explaining in part the earlier emergence of women professionals in these states. It was not until the eighteenth century with the five-fold expansion of trade in France that the stage was set for a "cultural explosion," to use Professor J.H. Plumb's expression. And as commercial wealth increased almost geometrically from generation to generation in the course of the eighteenth century, the number of women artists increased correspondingly. In the judgment of Elinor Barber, a leading authority on the bourgeoisie in 18th-century France, the new class of wealthy financiers and merchants became "the new patron of arts and letters." As a result, there were more French women artists active in the second half of that century than in all of the preceding centuries in French history. ${ }^{7}$ 
These three conditions - an abundance of male tutors, a relatively open society, and an expanding middle class - account for the phenomenal increase in women artists in France in the Enlightenment. The contrast between that period and the preceding centuries is striking. If one were to plot the number of known women artists for each century on a bar graph, the curve would rise slowly for the centuries before the seventeenth, rise more rapidly in the seventeenth, and then escalate sharply in the eighteenth. In terms of numbers, there were only three active women artists in France in the sixteenth century, about thirty in the seventeenth, and over two hundred in the eighteenth. The Académie du Saint-Luc alone registered 130 women as master painters in that century. ${ }^{8}$ Admittedly the number of women artists who worked prior to the eighteenth century may be greater than these figures indicate because of fewer extant records and greater anonymity in the earlier periods, but even if allowances are made for these considerations, the figures speak tellingly for the important rise of women artists. By the end of the century French women could boast that in the Salon of 1800 twenty-five of the 180 exhibitors were women.

\section{French Women Artists of the Enlightenment}

The identification of female artists in the eighteenth century is not difficult. By examining the registers of the art academies in the most important cities one can list the names of several hundred. The more difficult task is to separate the professionals from the amateurs and the successful from the dilettantes. The list below is compiled from research in the Bibliothèque d'Art et d'Archéologie in Paris, from visits to most of France's important art museums, and from a study of the literature and art exhibitions of the eighteenth century. ${ }^{9}$ The women are listed alphabetically in the second and third groups, but in the first group they are listed in the order in which they were generally ranked by their contemporaries. The sixth person in this category, Collot-Falconet, is listed last because she is the only sculptor. No two critics will agree upon any listing of artists, male or female, but for the purpose of making a study of the social, economic, and aesthetic aspects of women's art in the eighteenth century, the twenty-three women analyzed in this study should suffice. Even if one were to replace the names of five or six artists with others, none of the generalizations in this study would change appreciably.

\section{A. Most Successful:}

1. Marie Louise Elisabeth Vigée-Lebrun (1755-1842)

2. Adélaïde Labille-Guiard (1749-1803)

3. Anne Vallayer-Coster (1744-1818)

4. Marguerite Gérard (1761-1837)

$\begin{array}{cll}\begin{array}{c}\text { Married (M) } \\ \text { Single (S) }\end{array} & \begin{array}{l}\text { First Art } \\ \text { Teachers }\end{array} & \text { Academies } \\ \text { M } & \begin{array}{l}\text { Father, } \\ \text { Davesne, } \\ \text { Briard }\end{array} & \begin{array}{l}\text { Saint-Luc } \\ \text { Académie Royale } \\ \text { Eight Others }\end{array} \\ & \begin{array}{c}\text { F. Vincent, } \\ \text { M }\end{array} & \begin{array}{l}\text { Saint-Luc } \\ \text { Académie Royale }\end{array} \\ \text { (Twice) } & \begin{array}{l}\text { La Tour, } \\ \text { F.A. Vincent }\end{array} & \\ \text { M } & \text { Father } & \text { Académie Royale } \\ \text { S } & \text { Brother-in- } & \text { None } \\ & \text { Law (Fragonard) }\end{array}$


5. Marie-Guillemine Benoist, née Leroulx-Delaville (1768-1826)

$\begin{array}{lll}\text { M } & \begin{array}{l}\text { Vigée-Lebrun } \\ \text { David }\end{array} & \begin{array}{l}\text { Société des Arts } \\ \text { de Grand }\end{array} \\ \text { M } & \text { Falconet } & \begin{array}{l}\text { Imperial Academy } \\ \text { in St. Petersburg }\end{array}\end{array}$

B. Moderately Successful:

1. Madeleine-Françoise Basseporte (1701-1780)

2. Anne Rosalie Bocquet-Filleul (1753-1794)

3. Marie Geneviève Bouliar (1762-1825)

4. Gabrielle Capet (1761-1818)

5. Françoise Marie-Thérèse Duparc (1726-1778)

6. Marie-Suzanne Giroust-Roslin (1734-1772)

7. Jeanne Philiberte Ledoux (1767-1840)

8. Marie-Victoire Lemoine (1754-1820)

9. Marianne Loir (ca. 1715after 1769)

10. Adèle de Romance-Romany (1769-1846)

\begin{tabular}{|c|c|c|}
\hline $\mathrm{S}$ & $\begin{array}{l}\text { P.A. Robert, } \\
\text { Aubriet }\end{array}$ & None \\
\hline M & Father, Briard & Saint-Luc \\
\hline $\mathrm{S}$ & Greuze & None \\
\hline $\mathrm{S}$ & Labille-Guiard & None \\
\hline $\mathrm{S}$ & $\begin{array}{l}\text { Father, Van Loo, } \\
\text { Chardin? }\end{array}$ & $\begin{array}{l}\text { Académie de } \\
\text { Marseille }\end{array}$ \\
\hline M & $\begin{array}{l}\text { Vien, La Tour, } \\
\text { Roslin }\end{array}$ & Académie Royale \\
\hline $\mathrm{S}$ & Greuze & None \\
\hline $\mathrm{S}$ & $\begin{array}{l}\text { Ménageot, } \\
\text { Vigée-Lebrun? }\end{array}$ & None \\
\hline$S$ & $\begin{array}{l}\text { Father, Brother, } \\
\text { J. de Troy }\end{array}$ & $\begin{array}{l}\text { Académie de } \\
\text { Marseille }\end{array}$ \\
\hline 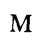 & Regnault & None \\
\hline
\end{tabular}

C. Honorable Mentions:

1. Gabrielle Bertrand-Beyer (1730-1790)

2. Marie-Renée-Geneviève Brossard de Beaulieu (1755-after 1835)

3. Aimée Duvivier (active 1786-1824)

4. Marquise de Grollier, née de Fuligny-Damas (1742-1828)

5. Catherine Lusurier (1753-1781)

6. Marie-Thérèse Reboul-Vien (1735-1806)

7. Nanine Vallain-Piètre (active 1787-1810)

$\begin{array}{lll}\text { M } & \text { Husband } & \begin{array}{l}\text { Imperial Academy } \\ \text { of Vienna }\end{array} \\ \text { M } & \text { Father, Greuze } & \begin{array}{l}\text { San Luca (Rome), } \\ \text { Académie de Lyon }\end{array} \\ \text { S } & \text { Father, Greuze ? } & \text { None } \\ \text { M } & \text { Spaendonck } & \text { None } \\ \text { S } & \text { Cousin (Drouais) } & \text { None } \\ \text { M } & \text { Vien } & \begin{array}{l}\text { Académie Royale, } \\ \text { San Luca (Rome) }\end{array} \\ \text { M } & \text { David, Suvée } & \text { None }\end{array}$

\section{Analysis and Evaluation}

All but four of the twenty-three women emerged from the broad spectrum of the middle class. If their fathers were not artists, they were goldsmiths, merchants, shopkeepers, tailors, jewelers, distillers, or government officials. Of the remaining four, two rose from the lower class - Capet and CollotFalconet - and two from the aristocracy - the Marquises of Grollier and of Romance-Romany. Another, the Comtesse Benoist, married into the nobility 
of the robe, but came from solid bourgeois stock.

These statistics should not be surprising because most of the intelligentsia - writers, musicians, philosophes - also emerged from the bourgeoisie, but what is different in their origins is that artists came from a lower stratum in that nebulous class. None of the female artists in the eighteenth century, for example, came from families engaged in the practice of law or jurisprudence, which was so often true for writers not only in France but throughout Europe.

Perhaps the most important change in the origins of the female artist is the tendency for an increasing number to come from non-painting families. Insofar as we have been able to study their lives, only eight of the twenty-three women received instruction from their fathers or brothers. Two others Gérard and Lusurier - learned from a brother-in-law and a cousin, respectively. Six married artists, but to say that the wife learned to paint from the husband is to conjecture erroneously because all six had learned to paint before their marriages. ${ }^{10}$ In sum, 50 percent of the women emerged from families in which painting was neither the vocation of the father nor of a close relative. Compared with earlier centuries this is a high percentage, and it negates the widespread myth that virtually all of the female artists prior to the nineteenth century were trained by their fathers or close relatives. More cases need to be studied, but it would appear that the familial, social, and economic ties of the medieval and Renaissance eras were breaking down along with the guild system in the century of the Enlightenment. By the middle of the century it was common for a bourgeois father to have a promising daughter tutored in the fine arts. The quality of the training depended upon the availability of tutors, female as well as male, and the pocketbook of the father.

Except for the two representatives of the aristocracy, the common motivation of women artists was economic gain, the driving force behind most entrepreneurs and professionals. It had long been fashionable for women, especially noble ladies, to dabble in art, but what was different in the eighteenth century was that it became increasingly profitable for them to become professionals. Most of the artists found painting to be a lucrative field of self-employment. The most successful - Vigée-Lebrun, Labille-Guiard, Benoist, and Collot-Falconet - received commissions as large as most of the male artists. In fact British male artists complained that Vigée-Lebrun was getting three times as much for a painting as Reynolds. Women also competed increasingly with males for royal patronage. The Bourbons patronized Vigée-Lebrun, Labille-Guiard, Vallayer-Coster, Basseporte, Bocquet-Filleul, and Marie Brossard; the Habsburgs employed BertrandBeyer at Schönbrunn; the Orange family commissioned Collot-Falconet at the Hague; Catherine the Great supported Collot-Falconet for twelve years and Vigée-Lebrun for six; the French revolutionary governments subsidized Labille-Guiard, Benoist, Capet, and Vallain-Piètre; Napoleon rewarded Benoist, Labille-Guiard, Capet and Gérard; and the aristocracy supported others, including Loir, Romance-Romany, and Duvivier.

Women's changing role in the arts was also reflected in their memberships in the art academies. Even though the Académie Royale of Paris set the quota of women artists at four during the beginning of the century, five of the 
twenty-three women analyzed in this study were admitted: Reboul-Vien in 1754, Giroust-Roslin and Vallayer-Coster in 1770, Vigée-Lebrun and Labille-Guiard in 1783. Vigée-Lebrun, Labille-Guiard, and Bocquet-Filleul were also members of the Académie de Saint-Luc. Within France VigéeLebrun held memberships in four academies and outside she had memberships in six of the most prestigious academies of Europe. ${ }^{11}$ Duparc and Loir were members of the Academy of Marseilles; Brossard was a member of the Academy of Lyons; and Benoist was an honorary member of the Société des Arts de Grand. Outside of France Collot-Falconet was given the status of agrégée in the Academy of Fine Arts of St. Petersburg; ReboulVien and Brossard were members of the Accademia di San Luca in Rome. In total, more than half of the women held memberships in one or more academies - an important achievement; and though they were not given the same privileges as men, this influx indicates again the great distance that they had advanced in the course of the eighteenth century.

Moving from the social to the psychological realm of the female artist, we walk with greater trepidation. What kind of woman became a professional painter? Most of the successful female artists either remained single (approximately 50 percent), left their husbands shortly after an unhappy marriage (a 17 percent divorce or separation rate), or married after their careers were well established. In short, 80 percent of the women were either single or were for all practical reasons unencumbered by marriage during the first twenty-five or thirty years of their lives. Few of the women combined an early, happy marriage with a successful career, and of these only three managed to raise a family: Benoist and Reboul-Vien each with three children and Giroust-Roslin with six. ${ }^{12}$ Even these exceptions fall far below the national average of children per French family for the century. For the most part, most women artists either did not marry or married late because they wanted to be free to pursue an independent career or because many men, aside from male artists, found them to be a strange breed of women: intellectually too independent, socially less acceptable, or politically too libertine. Relatively few of them played the dual role of wife and artist successfully. A high percentage escaped from unhappy marriages because a successful career made them economically independent of their husbands, and, in a few cases, Vallayer-Coster and Bocquet-Filleul in particular, their productivity dropped significantly after a late but happy marriage.

Why did most of the women artists avoid making historical, mythological, and allegorical pictures? In our judgment, the answer lies in the basic economic motivation behind the emergence of women in the fine arts in the eighteenth century. As we have seen, most of the women came from bourgeois families and depended upon the sale of portraits for their livelihood. They followed the example of the Italian artist, Rosalba Carriera, whose entrepreneurial techniques proved that a woman could ignore the academy's preference for history paintings and make a fortune in the less prestigious field of portraiture. Taking Paris by storm in 1720-21, she had more orders for portraits from the aristocracy and bourgeoisie than her studio could produce. Similarly, most of the female professionals in that century found instant markets for pictures of heads, busts, or half-lengths from the 
portrait-hungry clientele. The proud country gentry and the nouveau-riche bourgeoisie wanted portraits which female artists could turn out in great numbers. They were not interested in historical or mythological scenes to cover their drawing rooms. They shared Dr. Johnson's disdain for symbolic art: "I would rather see the portrait of a dog that I know than all the allegorical paintings they can shew me in the world." 13

It was this changing taste of the new Kulturtraeger - the affluent bourgeoisie and the country gentry - that dictated the style and genre of art for women in the marketplace in the eighteenth century. Why should VigéeLebrun produce history paintings when she could make over a million dollars selling portraits? Why should Labille-Guiard spend two years making a history painting for eight thousand francs, when she could earn many times that amount by painting portraits? With few exceptions most women had little desire to compete with male academicians in the production of the more prestigious but less profitable genre of history painting. Putting it differently, the typical female artist, a middle-class professional, was persuaded more by the profits of portraiture than by the prospects of academic praise through history paintings, whereas the male artist, longer associated with the hierarchical values of the academy and still looking in terms of royal and church patronage, was influenced more by the hope of artistic immortality through history painting than by the pursuit of lucrative portraiture.

The most controversial issue regarding women artists concerns the quality of their achievements. Was their collective effort significant? Were the most gifted women equal to or better than some of the male artists? When viewed in its entirety, the artistic production of women in eighteenth-century France is staggering, measuring into the thousands of separate pieces and covering the entire gamut of the fine arts.

Even if it is true that never before in history had so many female artists risen as professional competitors to males, were they as good? Could any of them compare in importance with the best male painters of the period: Boucher, Chardin, David, Fragonard, Greuze, La Tour, Robert, Vernet, Vincent, or Watteau? Most of the traditional art historians apparently do not think so for rarely is a French woman artist mentioned in the standard histories of the century. ${ }^{14}$ Why not?

In the judgment of most traditional art historians none of these women artists was an important innovator or painter of history. Most of the art critics from the eighteenth century to the present insist that artists must meet one of these requirements before being taken seriously. Few French women of the period met either. For the most part they were portraitists or painters of still lifes, and they often emulated the styles of their male tutors, sometimes so slavishly that their paintings are inseparable. Only a few were innovative: Vigée-Lebrun and Labille-Guiard were creative in positioning and adorning their subjects, and others, especially Vallayer-Coster, were creative in their floral and still-life arrangements, but, for the most part, they accepted and worked within the confines of the rococo or neoclassical styles of their time. In this sense the bold innovators of the century were men - Watteau, Chardin, Greuze, and David - and the women were creative disciples. The argument of the traditionalists follows, therefore, that even though Vigée-Lebrun, 
Labille-Guiard, and Benoist were superb portraitists, they have been excluded from art textbooks because they failed to measure up to the orthodox concepts of "great" art.

If art histories, however, are to go beyond the presentation of individual works of art within periods of stylistic development and to include the life of artists within the historical context, no significant art history can ignore the role of women artists within the art community of certain historical periods. Not all of the women artists merit inclusion, but certainly no art history of eighteenth-century France is complete without some discussion of the portraits of Vigée-Lebrun, Labille-Guiard, and Benoist, the still lifes of Vallayer-Coster, the genre paintings of Gérard, and the sculptures of CollotFalconet. In their time they were as celebrated as most of the male artists, earned as much money, received as favorable reviews, and fulfilled the artistic needs of their society. Undoubtedly a few were overpraised in their day, but the time has come for historians to restore some of them to the respected positions they enjoyed in the age of the Enlightenment.

Howard V. and Charlotte B. Evans
Central Michigan University

\section{Notes}

1 The literature of the early seventies is replete with feminist topics: Jacqueline Skiles and Manet McDevitt, A Documentary Herstory of Women Artists in Revolution (New York: Know Press 1971); Lucy Lippard, "Sexual Politics: Art Style," Art in America (September-October 1971); Ann Sutherland Harris, "College Art Association's Women's Caucus," Feminist Art Journal (April, 1972); Cindy Nemser, "The Women Artists' Movement," Feminist Art Journal (Winter 1973-74). The Feminist Art Journal ceased publication in 1977.

2 Vicki Lynn Hill, Female Artists, Past and Present (Berkeley: Women's History Research Center Inc., 1974); Germaine Greer, The Obstacle Race (New York: Farrar Straus Giroux, 1979).

${ }^{3}$ Great Britain, for example, which produced a number of important male artists for the first time in the eighteenth century, also produced a number of women artists for the first time.

${ }^{4}$ Only a few Italian women artists - Rosalba Carriera, Giovanna Fratellini, and Giulia Lama - stand out in the eighteenth century, whereas France produced a score or more.

5 The Westernization of Russia in the eighteenth century included the Westernization of its art, but most of Western art, in contrast to the production of icons, was either imported or created by Western artists in Russia until the end of that century. Consequently, it was not until the nineteenth century that Russian women became artists in the Western tradition. In Spain, where Western art reached its peak in the seventeenth century, Spanish women also learned to paint and sculpt in the same century, but few of them except Luise Roldan enjoyed the international reputation of the early Italian and Dutch women artists.

${ }^{6}$ Marie Louise Elisabeth Vigée-Lebrun, Souvenirs de Madame Vigée Le Brun, (Paris: Charpentier et Cie, 1869), I, p. 107, states: "Les femmes régnaient alors, la révolution les a détrônées." For support of the statement that life had become difficult for women painters during the revolution see Antoine Schapper, "Painting During the Revolution 1789-1799," French Painting 1774-1830, The Age of Revolution, pp. 108-9, hereafter cited as The Age of Revolution; also, Women Artists: 1550-1950, p. 45.

' Elinor G. Barber, Bourgeoisie in 18th-Century France (Princeton: Princeton Univ. Press, 1955), p. 97. For names and numbers of women artists one can turn to the collective findings of such writers as Ernst Guhl, Die Frauen in der Kunstgeschichte (Berlin: J. Guttenberg, 1858); Elizabeth F.L. Ellet, Women Artists in all Ages and Countries (New York: Harper, 1859); Hans Hildebrandt, Die Frau als bildende Künstlerin (Berlin: Mosse Buchhandlung, 
1928); Clara Erskine Clement, Women in the Fine Arts (Boston and New York: Houghton, Mifflin, and Co., 1904); Carmen G. Perez-Neu, Galeria universal de pintoras (Madrid: Editora Nacional, 1964); and Greer, Obstacle Race.

${ }^{8}$ For a list of members in the academy see Jules Guiffre, "Histoire de l'Académie de Saint-Luc," Archives de l'art français, nouvelle periode, 9 (1925), p. $161 \mathrm{ff}$.

9 As a rule of thumb, we have used the years 1665 and 1765 as the limits of the birthdates of the artists, reasoning that anyone born before 1665 belongs to the seventeenth century and anyone born after 1765 belongs to the nineteenth. In a few instances an individual born after the year 1765 is included if she exhibited enough paintings before 1800. A number of women straddle the century, such as Benoist, Bouliar, Capet, Duvivier, Gérard, Ledoux, Lemoine, RomanceRomany, Vallain-Piètre, and Vigée-Lebrun, but no discussion of the eighteenth century would be complete without them. On the other hand, as much as we would have liked to include Pauline Auzou, Constance Marie Charpentier, Eulalie Cornillaud-Morin, JeanneElisabeth Gabiou-Chaudet, Marie Eléonore Godefroy, Antoinette Cecile Hortense Haudebourt-Lescot, Elise Lebarbier-Bruyère, Césarine-Henriette-Flore Mirvault-Davin, and Mme Villers, they clearly lie outside the eighteenth century. Of these, Charpentier comes closest to the cutoff date, but almost all of her surviving works belong to the nineteenth century.

${ }^{10}$ These include Bertrand-Beyer, Collot-Falconet, Giroust-Roslin, Labille-Guiard (second marriage to Vincent), Reboul-Vien, Romance-Romany.

$"$ On the title page of her Souvenirs Vigée-Lebrun lists the nine academies of which she was a member. A complete title of her memoirs thus reads: Souvenirs de Madame Vigée Le Brun de l'Académie Royale de Paris, de Rouen, de Saint-Luc de Rome et d'Arcadie de Parme et de Bologne, de Saint-Pétersbourg, de Berlin, de Genève et Avignon. As we have seen, she also was a member of the Academie de Saint-Luc in Paris before it was abolished.

12 The women who remained single were identified in the lists of women artists. Vigée-Lebrun, Collot-Falconet, Labille-Guiard (her first husband), Romance-Romany were unhappily married. Vallayer-Coster married at age 36, Giroust-Roslin at 25, and Bertrand-Beyer at 25 or older. Vigée-Lebrun, Collot-Falconet, and Bocquet-Filleul had one child each, but they do not fall into the category of women who combined an early marriage with a successful career. The number of children, if any, of Bertrand-Beyer, Grollier, and Vallain-Piètre, who all seemed to have been successfully married, is not known.

${ }^{13}$ Dorothy M. Mayer, Angelica Kauffmann, R.A. (Gerrards Cross, Buckinghamshire: Colin Smythe Ltd., 1972), p. 28.

14 This statement is true for most art histories, but it is particularly true for Julius S. Held and Donald Posner's 17th and 18th-Century Art (Englewood Cliffs, N.J.: Prentice-Hall, Inc., and New York: Harry N. Abrams, Inc., n.d.). Not a single name of a woman artist appears in the index, and when Posner discusses Falconet's Equestrian Monument of Peter the Great, he does not mention Collot-Falconet who sculpted the head of Peter. 